\title{
The (Ir)relevance of Transnational Public Policy in Investment Treaty Arbitration - A Reply to Jean-Michel Marcoux
}

\author{
Eric De Brabandere \\ Grotius Centre for International Legal Studies, Leiden University, \\ Leiden, The Netherlands \\ e.c.p.d.c.de.brabandere@law.leidenuniv.nl
}

\begin{abstract}
In his article 'Transnational Public Policy as a Vehicle to Impose Human Rights Obligations in International Investment Arbitration', Jean-Michel Marcoux investigates whether international investment tribunals can rely on transnational public policy to impose human rights obligations on investors. While I generally side with the idea that international human rights as such are highly relevant in (some) international investment arbitrations, I argue in this article that transnational or truly international public policy as a concept is largely, and as a matter of principle, irrelevant in investment treaty arbitration. Secondly, even if one were to accept that transnational public policy has a role to play, I question the usefulness of framing various human rights issues as questions of 'transnational public policy'.
\end{abstract}

\section{Keywords}

human rights - investment treaty arbitration - jus cogens - mandatory rules - public policy

* Professor of International Dispute Settlement and Director, Grotius Centre for International Legal Studies, Leiden University; Attorney-at-Law (DMDB Law, Brussels). 
In his article 'Transnational Public Policy as a Vehicle to Impose Human Rights Obligations in International Investment Arbitration,', Jean-Michel Marcoux investigates whether international investment tribunals can rely on transnational public policy to impose human rights obligations on investors. Marcoux himself describes the positive outcome of his analysis as innovative and 'somehow radical' in his conclusions, and concedes that dismissing an investor's claim because of 'illegality' under international law based on the doctrine of transnational public would make the latter a 'blunt tool'.2

While I generally side with the idea that international human rights as such are highly relevant in (some) international investment arbitrations, I fundamentally disagree with the proposition that transnational or truly international public policy has a significant role to play in investment treaty arbitrations, both as a matter of principle and as a way to present or frame human rights violations by foreign investors. I therefore argue that transnational or truly international public policy as a concept is largely, and as a matter of principle, irrelevant in investment treaty arbitration. Secondly, even if one were to accept that transnational public policy has a role to play, I question the usefulness and purpose of framing various human rights questions, including the 'corporate responsibility to respect human rights', in investment treaty disputes as questions of 'transnational public policy'.

Throughout my reply, I also point to the need to not take at 'face value' the argumentative practices of decisions of international courts and tribunals. More specifically, the references made by some arbitral tribunals in their awards to 'transnational public policy' should not always be read as explicit endorsements of the relevance of the concept in investment treaty arbitration. While I recognize the importance of decisions of arbitral tribunals in shaping international investment law, ${ }^{3}$ arbitral tribunals do not have a monopoly on the 'correct' interpretation of international investment treaties and their legal construction of a decision and obiter dicta should not always be taken as objectively or categorically representing the current state of the law. The legal

1 Jean-Michel Marcoux, 'Transnational Public Policy as a Vehicle to Impose Human Rights Obligations in International Investment Arbitration' (2020) 21(6) JWIT 8o9-46.

2 ibid.

3 See the contributions by David D Caron, 'Regulating Opacity: Shaping How Tribunals Think' and Judith A E Gill, 'The Development of Legal Argument in Arbitration: Law as an Afterthought: Is It Time To Recalibrate Our Approach?' in David D Caron and others (eds) Practising Virtue: Inside International Arbitration (OUP 2015) 379-406. 
'truth' as contained in arbitral awards can in some cases be relativized, or at least not generalized.

Before turning to the substance of my reply, let me add that my arguments are valid for treaty-based investment arbitrations only. As I will point out in the first section, (transnational or international) public policy as a concept derives from a commercial arbitration or a private international law view on the applicability of certain (international) legal norms, and hence does retain much of its relevance in contract-based arbitrations, either in the international commercial arbitration or in the investor-State arbitration context. However, as I will argue, transposing as such the application of transnational public policy to treaty-based arbitrations is inapposite. Arbitration

In line with Marcoux's use of 'public policy', it is important to distinguish the various emanations of the concept. There are indeed different conceptions of public policy. ${ }^{4}$ The different conceptions in essence revolve around the question of whether the public policy exception is viewed as one linked to the public policy of the State (domestic public policy or international public policy of the State concerned), or whether it is viewed as a public policy transcending one specific legal order (truly international public policy or transnational public policy). Marcoux focuses on the latter use of the concept, and for the sake of consistency, I will here also use 'transnational public policy' to denote a public policy that represents an 'international consensus as to universal standards and accepted norms of conduct that must always apply' ${ }^{5}$

In general terms, public policy understood as domestic public policy or international public policy of a State mostly is relevant in the context of delineating the arbitrability of disputes, ${ }^{6}$ and the enforcement of arbitral awards. Transnational public policy has a slightly different ambit and scope

4 See in extenso Pierre Lalive, 'Transnational (or Truly International) Public Policy and International Arbitration' in Pieter Sanders (ed), Comparative Arbitration Practice and Public Policy in Arbitration (Kluwer Law International 1987) 258-318.

5 Committee on International Commercial Arbitration, 'Interim Report on Public Policy as a Bar to Enforcement of International Arbitral Awards' in International Law Association Report of the Sixty-Ninth Conference (interim report, London 2000) 2.

6 See Loukas A Mistelis, 'Arbitrability - International and Comparative Perspectives' in Loukas A Mistelis and Stavros Brekoulakis (eds), Arbitrability: International and Comparative Perspectives (Kluwer Law International 2009) 1-18. 
of application: its application implies that arbitrators should disregard the lex contractus on a certain issue if doing so would be in violation thereof. ${ }^{7}$

Aside from the fact that (the relevance of) transnational public policy is not universally accepted, ${ }^{8}$ what 'the limitation to party autonomy in the determination of the law applicable to the merits through the concept of transnational public policy'9 means in practice, is still open to debate. Two interconnected consequences seem to stand out, which are of relevance to contract-based arbitrations, whether in the context of international commercial arbitration or investor-State arbitration. First, it has been argued that a contract may be declared invalid or null and void if, for instance, it was procured by corruption or if the contract's subject-matter is corruption or any other norm considered as part of transitional public policy. ${ }^{10}$ Secondly, the implication of transnational public policy might result in an arbitral tribunal overriding the lex contractus chosen by the parties or otherwise applicable to the dispute. ${ }^{11}$ In sum, the effect of transnational public policy might result in either discarding the application of certain norms because they are contrary to transitional public policy, or on the positive side, impose the application of transitional public policy norms irrespective of the applicable law. ${ }^{12}$ Aside from these two 'functions' in relation to the law applicable to the merits, there seems to be a recent tendency to consider that a violation of transnational public policy does not in and of itself imply the inarbitrability of the dispute, ${ }^{13}$ that is the arbitral tribunal can declare itself competent to hear the dispute irrespective of the presence of a violation of transnational public policy.

Beyond the practical application and meaning of it, the most important aspect of transnational public policy for the question I address in this reply, however, is its origins or raison d'être. I already made clear that the concept principally finds application in international commercial arbitration. Transnational public policy in essence is a concept that makes sense if viewed

7 Emmanuel Gaillard, Legal Theory of International Arbitration (Brill Nijhoff 2010) para 118.

8 See notably Michael Pryles, 'Reflections on Transnational Public Policy' (2007) 24 J Intl Arb 1.

$9 \quad$ Gaillard (n 7$)$ para 115.

$10 \quad$ Lalive (n 4$)$ paras 111 et seq. See also Gaillard (n 7$)$ para 117.

11 Lalive (n 4) para 186.

12 ibid.

13 Yas Banifatemi, "The Impact of Corruption on "Gateway Issues" of Arbitrability, Jurisdiction, Admissibility and Procedural Issues' in Domitille Baizeau and Richard Kreindler (eds), Addressing Issues of Corruption in International Commercial and Investment Arbitration, (ICC Publication No 768E, 2015) 16-31, para 13. See also Marie Louise Seelig, 'The Notion of Transnational Public Policy and Its Impact on Jurisdiction, Arbitrability and Admissibility' (2009) Belgrade Law Review 116-34, 131. 
form a private international law or commercial law perspective. The idea behind the concept is that there are certain norms which find application, irrespective of the law to be applied by an arbitral tribunal as decided by the parties, because these norms are considered necessary to 'maintain minimum standards of conduct and behaviour in international commercial relations.' ${ }^{14}$ As aptly put by the Tribunal in Niko Resources $v$ Bangladesh: ${ }^{15}$

as a principle of international public policy, the prohibition of bribery overrides the general principle of party autonomy which is widely recognised in international and comparative law. Normally, arbitral tribunals respect and give effect to contracts concluded by the parties which agreed on the arbitration clause from which they derive their powers. However, party autonomy is not without limits. In international transactions the most important of such limits is that of international public policy. A contract in conflict with international public policy cannot be given effect by arbitrators. ${ }^{16}$

All this derives from the autonomy of international arbitration as such, (the limits to) party autonomy and the fact that arbitral tribunals have no forum. ${ }^{17}$ As explained by Pierre Lalive:

While he is clearly not an organ of the State, the international arbitrator is not acting in a legal vacuum and is not called upon to decide, so to speak, as if he did not belong to this world! The question may be raised here, in passing (and it appears to be connected with that of the existence of a transnational public policy) whether the arbitrator is not, perhaps, the organ of the international community, be it the community of States or the "international community of page businessmen" (in which more and more States and State organs appear to be active) or both international communities. ${ }^{18}$

\footnotetext{
14 Andrew Barraclough and Jeff Waincmayer, 'Mandatory Rules of Law in International Commercial Arbitration' (2005) 6(2) Melbourne J Intl L 205-44, 219.

15 Niko Resources (Bangladesh) Ltd $v$ Bangladesh Petroleum Exploration \& Production CompanyLimited ('Bapex') and Bangladesh Oil Gas andMineral Corporation ('Petrobangla'), ICSID Case No ARB/10/18, Decision on the Corruption Claim (25 February 2019).

16 ibid para 434.

17 Jean-Baptiste Racine, L'Arbitrage Commercial International et L'Ordre Public (LGDJ 1999) 163 .

18 Lalive (n 4) 258-318, para 44.
} 
I will come back to these issues in the next section. However, before turning to the irrelevance of the concept of 'transnational public policy' in investment treaty arbitration, I should briefly discuss its content. Transnational public policy is a narrow category of norms and principles. It has been described by Marcoux, in a previous publication, as encompassing the fundamental values and interests of the international community as a whole, without being attached to any domestic legal order in particular.'19 The International Law Association (ILA) Committee on Public Policy has defined it as 'comprising fundamental rules of natural law, principles of universal justice, jus cogens in public international law, and the general principles of morality accepted by what are referred to as "civilized nations". ${ }^{20}$ On a more concrete level, the prohibition of apartheid, drug trafficking, and corruption, have often been cited as examples of transnational public policy, ${ }^{21}$ Others have described it as including 'slavery, bribery, piracy, murder, terrorism, and corruption. ${ }^{22}$ In general, rather than trying to establish an exhaustive list, the 'consensus' of what norms constitute transnational public policy may be found through an 'analysis of the solutions adopted in national laws and in international instruments having addressed the matter.'23 These definitions or proposals to give concrete contents to transnational public policy however, are largely based on the private nature of the dispute and the arbitral proceedings; they are, as a consequence, irrelevant in an investment treaty arbitration context.

\section{The Irrelevance of (Transnational) Public Policy in Investment Treaty Arbitration}

While Marcoux seems to accept that transnational public policy is firmly grounded in international commercial arbitration - which by the way obfuscates that there are opponents to the very concept of transnational public

19 Jean-Michel Marcoux, 'Transnational Public Policy as an International Practice in Investment Arbitration' (2019) 10 JIDS 496-515, 498.

20 Audley Sheppard, 'Interim ILA Report on Public Policy as a Bar to Enforcement of International Arbitral Awards' (2003) 19(2) Arb Intl 217-48, 220.

21 Donald Francis Donovan, 'Investment Treaty Arbitration' in George A Bermann and Loukas Mistelis (eds), Mandatory Rules in International Arbitration (Juris 2011) 275-9o, at 283 .

22 Margaret Moses, 'Public Policy: National, International and Transnational' (Kluwer Arbitration Blog, 12 November 2018) <http://arbitrationblog.kluwerarbitration.com/ 2018/11/12/public-policy-national-international-and-transnational/?doing_wp_cron=1591 876464.9858610630035400390625> accessed 16 September 2020.

23 Gaillard (n 7$)$ para 118. 
policy and its relevance ${ }^{24}$ - I disagree with Marcoux that the use of the transnational public policy in commercial arbitration can easily be transposed to investment treaty arbitration.

The most important reason for my disagreement, and I reiterate here that I limit my criticism to treaty-based investment arbitrations, is that the reasons behind the application of transnational public policy in international commercial arbitration are to a large extent alien to investment treaty arbitration.

To a certain extent the question why transnational public policy should be applied, or is generally applied, in international commercial arbitration is answered indirectly by the definitions of transnational public policy: it is composed of norms which are considered so fundamental as to warrant overriding the law otherwise applicable to the dispute. These norms function as a sort of 'private international law jus cogens'. It is for that reason that it is not surprising that there is either a considerable overlap between the norms comprised under transitional public policy and jus cogens norms, such as slavery, or that there is a renvoi to the public international peremptory norms as the ILA definition cited above has shown. At the same time, the application of transnational public policy in commercial arbitration and the application of jus cogens in international law (and investment treaty arbitration) results from very different rationalities. It has for that reason been considered that jus cogens is the international law counterpart of transnational public policy in the field of international transactions, ${ }^{25}$ thus hinting at a clear separation of the respective relevance of jus cogens and transnational public in both legal regimes.

As explained in the previous section, the application of transnational public policy in commercial arbitration results from a combination of the fact that an arbitral tribunal has no forum and that party autonomy has limits. Precisely because arbitral tribunals have no forum and are based on the will of the parties to the arbitration agreement who are autonomous in defining the mandate of such a tribunal, there would be a need to put 'limits' to what the parties can do. They cannot, as a consequence, request from an arbitral tribunal to enforce obligations that run counter the norms comprised under 'transitional public policy'. In investment treaty arbitration, by contrast, the same effect is more or less achieved by the concept of jus cogens, although the consequences of violation of jus cogens are not fully identical but a detailed discussion of this is beyond the scope of this article. ${ }^{26}$

\footnotetext{
24 See Pryles (n 8).

25 Gaillard (n 7$)$ para 118.

26 See on this Daniel Costelloe, Legal Consequences of Peremptory Norms in International Law (CUP 2017).
} 
Based on this brief summary, the very irrelevance of the entire concept of 'transitional public policy' in investment treaty arbitration should have become clear. The baselines in both commercial arbitration and investment treaty arbitrations are different. ${ }^{27}$

First, treaty-based arbitral tribunals derive their mandate from an international treaty signed by States. The access of foreign investors to arbitration is granted through the explicit consent by States which allow the investors of one or more States, to bring a claim related to an investment against another State without the former State's intervention. Such consent is generally considered to constitute an 'offer to arbitrate' by the State, ${ }^{28}$ which may then be accepted by the foreign investor ${ }^{29}$ through the submission of a request for arbitration. The origin of the tribunal's power thus lies in the treaty and the consent of both States. Treaty-based investment tribunals are different from 'forum-less' arbitral tribunals in international commercial arbitration - the legitimacy and authority of investment treaty tribunals derives from the international legal system which generally and quite uncontroversially grants States the right to consent to have disputes regarding their international legal obligations settled through arbitration or otherwise, ${ }^{30}$ even if such right is granted to or exercised by a non-State entity.

While all this may seem trivial or academic, and perhaps seem to not differ as profoundly from commercial arbitration since consent in both cases forms the basis of the tribunal's mandate, there is an important and essential consequence of this fact: because the tribunal is treaty-based, the tribunal is part of the international legal order - public international law is, so to say, the tribunal's 'forum'. Notions such as autonomy of international arbitration or the fact that tribunals have no forum are thus to a large extent alien to investment treaty arbitration since the latter's legitimacy, nature and mandate differ fundamentally form international commercial arbitration.

27 See Eric De Brabandere, Investment Treaty Arbitration as Public International Law: Procedural Aspects and Implications (CUP 2014) 21 et seq.

28 See for example Asian Agricultural Products Ltd (AAPL) v Republic of Sri Lanka, ICSID Case No ARB $/ 87 / 3$, Award (27 June 199o) 246 et seq.

29 On the need for the consent of the foreign investor see, American Manufacturing and Trading, Inc v Zaire, ICSID Case No ARB/93/1, Award (21 February 1997) 23 et seq.

30 It is for that reason also that the notion of arbitrability of a dispute is entirely irrelevant in investment treaty arbitration. Even if one were to take the-now seemingly abandonedapproach that in international commercial arbitration, in the event of the presence of an element of transnational public policy which would hinder the private settlement of the dispute through arbitration, the case would be inarbitrable, such by its very nature has no place in treaty-based investment arbitration. States have no limit on the type of disputes they, as States, can settle through arbitration. 
This brings me to my second point. While I generally agree with the proposition that investment treaty arbitration is sui generis in the sense that the combination of the applicable legal frameworks may be unique and applied concomitantly in an international investment dispute, ${ }^{31}$ the fact remains that, if a tribunal is mandated to settle a treaty claim, this is governed by the principles applicable to the international responsibility of States and other norms of public international law. Aside from the fact that the principle of party autonomy, including in defining the law applicable to the merits of the dispute, finds application in investment treaty arbitration also, ${ }^{32}$ public international law applies to the dispute. The consequence of this, for the purposes of my argument here, is that there is no need to put 'limits' on party autonomy. International law generally applies, including possible peremptory norms and their effects. There thus is no need for a transnational public policy to 'trump' or overrule the law as chosen by the parties: 'higher' norms (as understood in the concept of transnational public policy) are part of (and even mostly derived from) the international law applicable to the disputes, and no 'higher' norms can trump international law which has its own peremptory norms.

There is of course one caveat: the principle I have just enounced does not stand similarly in case a treaty-based tribunals hears a contract-based claim. ${ }^{33}$ In that case of course, the domestic law chosen by the parties is the applicable legal system in order to assess whether there has been a breach of a contractual obligation, and as with contract-based investment tribunals, the situation cannot be compared to treaty claims before international investment tribunals. A treaty-based tribunal's competence to hear a contract-based claim can occur when tribunals interpret the treaty dispute settlement clause so as to encompass contract claims. As for instance noted by the Annulment Committee in Vivendi I:

Article 8 [of the BIT] deals generally with disputes "relating to investments made under this Agreement between one Contracting Party and an investor of the other Contracting Party" ... Article 8 does not use a

31 Cf Zachary Douglas, The International Law of Investment Treaty Claims (CUP 2009) 6.

32 See Convention on the Settlement of Investment Disputes Between States and Nationals of Other States (signed 18 March 1965, entered into force 14 October 1966) (ICSID Convention) art 42.

33 See SGS Société Générale de Surveillance SA v Republic of the Philippines, ICSID Case No ARB/o2/6, Decision of the Tribunal on Objections to Jurisdiction (29 January 2004) para 132. 
narrower formulation, requiring that the investor's claim allege a breach of the BIT itself. Read literally, the requirements for arbitral jurisdiction in Article 8 do not necessitate that the Claimant allege a breach of the BIT itself: it is sufficient that the dispute relate to an investment made under the BIT. ${ }^{34}$

In such cases, the law applicable to the contract as set by the contract's choice of law clause applies to the merits. This in turn may require the application of any provision of transnational public policy since here the autonomy of the parties may be considered to be similarly subjected to limitations despite the treatynature of the arbitral tribunal as in international commercial arbitration.

The situation of a treaty-based tribunals hearing a contract-based claim can also occur when treaty-based arbitral tribunals need to establish the occurrence of a breach of an 'umbrella clause'. ${ }^{35}$ The presence of such a clause implies that if a State breaches one of its (contractual) obligations towards the investor, this at the same time may constitute a violation of the treaty obligation contained in the umbrella clause. But the law to be applied by the tribunal does not change. ${ }^{36} \mathrm{~A}$ tribunal then needs to establish State responsibility based on public international law governing responsibility, but the content of the substantive obligations between the host State and the foreign investor subject of the umbrella clauses remains unaffected. ${ }^{37}$ As put by the Tribunal in $S G S v$ Philippines:

[the umbrella clause] does not convert non-binding domestic blandishments into binding international obligations. It does not convert questions of contract law into questions of treaty law. In particular it does not change the proper law of the CISS Agreement from the law of the Philippines to international law. ${ }^{38}$

34 Compañiá de Aguas del Aconquija SA and Vivendi Universal (formerly Compagnie Générale des Eaux) v Argentine Republic, ICSID Case No ARB/97/3, Decision on Annulment (3 July 2002) para 55. See also SGS v Republic of the Philippines (n 33) paras 95 and 132. On 'umbrella clauses' and their effects, see Stephan W Schill, 'Enabling Private Ordering: Function, Scope and Effect of Umbrella Clauses in International Investment Treaties' (2009) 18 Minn J Intl L 1-96.

36 CMS Gas Transmission Company v The Argentine Republic, ICSID Case No ARB/o1/8, Decision on Annulment (25 September 2007) para 95.

37 Schill (n 35) 61.

$38 \quad S G S v$ Republic of the Philippines (n 33) para 126. 
But let me turn back to the main principle that there is no need for a transnational public policy to 'trump' or overrule the law as chosen by the parties and illustrate this with one specific example: legality requirements. I can surely agree with the proposition that every investment in order to qualify as such must exist within a domestic legal system. ${ }^{39}$ This is not to say that municipal law has a determinant role to play for the qualification of protected investments, since, as is widely acknowledged, it is the applicable international investment treaty which regulates which types of investments are protected under the treaty. ${ }^{40}$ However, whether there is an investment is a matter regulated by domestic law, as are the scope and nature of the rights granted, and, for example, the existence and scope of governmental commitments towards the investment. ${ }^{41}$ But whether the investment is an investment protected under the applicable investment treaty, and thus qualifies as such under that treaty, is regulated by international law.

Some investment treaties, as an application of these principles, explicitly provide for an obligation for investments to be made in accordance with the domestic laws of the host State, so-called 'legality requirements' or 'in accordance with the law' provisions. A typical example can be found in Article 1 of the 2006 French Model BIT, which contains in its definition of investment the following sentence:

It is understood that those investments are investments which have already been made or may be made subsequent to the entering into force of this Agreement, in accordance with the legislation of the Contracting Party on the territory or in the maritime area of which the investment is made. ${ }^{42}$

When such a clause is added to an investment agreement, the non-fulfilment of the obligations in respect of, say, human rights under domestic law may depending on the precise formulation of the treaty - impact the admissibility of claims based on the treaty, or the existence, for the purposes of the treaty, of a covered investment and hence the jurisdiction of the tribunal.

39 Andrew Newcombe and Lluis Paradell, Law and Practice of Investment Treaties: Standards of Treatment (Kluwer Law International 2009) para 2.11.

40 ibid.

41 ibid para 2.12 .

42 Draft Agreement Between the Government of the Republic of France and the Government of the Republic of (...) on the Reciprocal Promotion and Protection of Investments (10 July 2020) art 1. 
Through the treaty's renvoi to domestic law, rights derived from contracts for example need to respect of the laws and regulations of the host State. A transnational public policy perspective on a contract procured by corruption would result in overriding the validity of the contract to not recognize rights derived from such a contract. From the perspective of investment treaty arbitration, if the investment was for instance acquired in breach of domestic legislation on corruption, the investor would simply have no 'investment' which could give rise to 'protection' under the treaty. Then, from the perspective of a treaty-based investment arbitration, a decision of a tribunal declining jurisdiction or declaring the dispute inadmissible, results not, strictly speaking, from an application of the concept of corruption as part of 'transnational public policy', but rather from the application of the investment treaty which requires an investment to be made in accordance with the legislation of the host State. In other words, the legal norm which functions as the basis on which jurisdiction is declined, or the case declared inadmissible, is not transnational public policy, but a treaty norm. It is thus not through the application of transnational public policy that the tribunal has no jurisdiction, but because there is no 'investment' as required by the treaty. On the face of it, the norms applied are the same, but the legal system which demands the application of the norms is fundamentally different.

Before turning to my next point, I need to concede that public policy does play a role in relation to the recognition and enforcement of arbitral awards, which may be refused on the basis of the public policy ground found in Article $\mathrm{V}(2)(\mathrm{b})$ of the New York Convention. Such a possibility depends very much on the presence or not of public policy considerations inherent to each State, but, it has been argued, implies also transnational public policy. ${ }^{43}$ The latter scenario, perhaps, is the only area in which the concept has any relevance in investment treaty arbitration, and then only in cases of non-ICSID investment treaty arbitration, since arbitral awards rendered in investment treaty arbitrations under rules other than the ICSID Convention, are subjected to scrutiny under the New York Convention for those States which are party to it. A similar provision moreover is included in Article 36 (b)(ii) of the UNCITRAL Model Law. But this is not the subject of the enquiry.

43 See for a discussion Hossein Fazilatfar, 'Transnational Public Policy: Does It Function from Arbitrability to Enforcement' (2011-2012) 3 City U Hong Kong L Rev 289. 


\section{Overstretching the Importance of Certain Pronouncements of} Arbitral Tribunals

One of the reasons, conceivably, for the rather positive appraisal by Marcoux of the potential of transnational public policy in investment treaty arbitration, is the series of cases in which arbitral tribunals have made references to transnational public policy. Marcoux's article rests on a selection of certain cases to support an argument, but - as is often the case in scholarship - one could easily find a series of cases in which tribunals, having dealt with the same matters, have not made reference to transnational public policy, or have in actual fact denied any relevance to transnational public policy. An example is the Tribunal in Phoenix Action Ltd $v$ Czech Republic, ${ }^{44}$ based on the Czech Republic-Israel BIT, which concerned questions of corporate restructuring:

In the instant case, no question of violation of a national principle of good faith or of international public policy related with corruption or deceitful conduct is at stake. The Tribunal is concerned here with the international principle of good faith as applied to the international arbitration mechanism of ICSID. The Tribunal has to prevent an abuse of the system of international investment protection under the ICSID Convention, in ensuring that only investments that are made in compliance with the international principle of good faith and do not attempt to misuse the system are protected. ${ }^{45}$

This of course is inherent in legal arguments, since one tends to focus on those cases which serve to make an argument, and even more so when the argument attempts to develop an innovative approach to a certain topic. I have no issue with that. However, more importantly, Marcoux relies in my view too heavily on obiter dicta or other pronunciations by arbitral tribunals which mention transnational public policy, taking the language and terminology of tribunals at face value: 'transnational public policy' being used in some decisions does not mean that the tribunal is in fact endorsing the relevance of the concept in investment treaty arbitration as a matter of law. In other instances, reading transnational public policy into decisions or pronouncements simply because of connotations between the terms used by the tribunal and the norms which are considered part of transnational public policy, in my view should be subjected to caution and critically assessed.

44 Phoenix Action Ltd v Czech Republic, ICSID Case No ARB/o6/5, Award (15 April 2009).

45 ibid para 113. 
A couple of examples here will illustrate my point. First, references to World Duty Free $v$ Kenya ${ }^{46}$ are inapposite: the case is a contract-based investment arbitration, and hence it is completely unsurprising that the Tribunal referred to transnational public policy when dealing with the question whether the claimant could validly invoke rights tainted by corruption. Similarly, the highly interesting case Niko Resources $v$ Bangladesh, ${ }^{47}$ is also a contract-based arbitration and hence of limited usefulness to draw conclusions as to the application of transnational public policy in a treaty-based context.

A second example is Inceysa $v$ El Salvador, ${ }^{48}$ which was based on the bilateral investment treaty (BIT) between El Salvador and Spain. The Tribunal's jurisdiction in Inceysa was predetermined by the requirement of an investment being made in accordance with Salvadoran law. At a certain point, the Tribunal engaged in a discussion of, and in fact dedicated several paragraphs of the decisions to, 'international public policy' ${ }^{49}$ It remains first of all unclear whether reference is made to 'transnational public policy' or whether reference is made to the (international) public policy of El Salvador. However, what matters here is the statement of the Tribunal that

the inclusion of the clause 'in accordance with law' in various BIT provisions is a clear manifestation of said international public policy, which demonstrates the clear and obvious intent of the signatory States to exclude from its protection investments made in violation of the internal laws of each of them..$^{50}$

Whether or not the legality requirement is an emanation of an 'international public policy' is irrelevant. The treaty provision, as put above, merely requires that investments conform to the domestic law of the host State. What the Tribunal does, but in a rather opaque manner, is precisely what I have explained above, namely establish an illegality at the level of the investment, which in turn from a normative perspective implies that there is no 'covered investment':

46 World Duty Free Company Limited v Republic of Kenya, ICSID Case No ARB/oo/7, Award (4 October 2006).

$47 \quad$ Niko Resources $v$ Bangladesh (n 15).

48 Inceysa Vallisoletana, SL v Republic of El Salvador, ICSID Case No ARB/o3/26, Award (2 August 2006).

49 ibid paras 245 et seq.

$5^{\circ} \quad$ ibid paras 246 . 
The Tribunal agrees with El Salvador and notes that an interpretation of the Agreement that would afford protection to investments made fraudulently would have enormous repercussions for those States which signed agreements for reciprocal protection of investments and included the clause 'in accordance with law, in order to exclude from the protection of said treaties the investments not made in accordance with the laws and other norms of the State that receives the investment. ${ }^{51}$

Whether or not a legality requirement is an emanation of public policy is in such exercise irrelevant, leaving aside the correctness of the statement.

A third example is Churchill Mining PLC and Planet Mining Pty Ltd $v$ Indonesia. ${ }^{52}$ In that case, which involved allegations of fraud and corruption in obtaining the investment, the Tribunal also referred to 'transnational public policy' on several instances:

493. ... particularly serious cases of fraudulent conduct, such as corruption, have been held to be contrary to international or transnational public policy....

508. The Tribunal agrees with the Respondent that claims arising from rights based on fraud or forgery which a claimant deliberately or unreasonably ignored are inadmissible as a matter of international public policy....

However, when one looks at the actual ratio decidendi, it is clear that the Tribunal justified its decision not on the presence of a 'transnational public policy', but on the principles of good faith and abuse of process, which led the Tribunal to declare the claim inadmissible. ${ }^{53}$

Finally, the reference in Unión Fenosa Gas $v$ Egypt ${ }^{54}$ to 'transnational public policy' are pure obiter dicta since, in the end, there was no finding of corruption. Moreover, keeping in mind the principles set out in the first section of this article, the obiter is written in very general terms, which does not permit to identify the true scope, if any, of the application of transnational public policy to the case or to investment treaty arbitration in general.

$5^{1} \quad$ ibid paras 249 et seq.

$5^{2}$ Churchill Mining PLC and Planet Mining Pty Ltd v Republic of Indonesia, ICSID Case Nos ARB/12/14 and ARB/12/4O, Award (6 December 2016).

53 ibid para 528 .

54 Unión Fenosa Gas SA v Arab Republic of Egypt, ICSID Case No ARB/14/4, Award (31 August 2018). 
Beyond the principled reasons I have for discarding the application of transnational public policy in investment treaty arbitration, I doubt that presenting or conceptualizing norms as part of transnational public policy has any (legal) benefit.

\section{Do We Really Need Transnational Public Policy to Frame Human} Rights Considerations Before Investment Treaty Tribunals?

Marcoux focuses on three distinct 'norms' which would be 'conceptualized as norms of transnational public policy'. These three 'norms' are the protection of fundamental human rights, a corporate responsibility to respect human rights, and the rights of indigenous peoples. I agree that this would be an innovative approach to address human rights issues in investment arbitration, but in this last section of my reply, I would like to question the usefulness of framing these three 'norms' as part of transnational public policy. I am not convinced that 'conceptualizing these as norms of transnational public policy' serves any useful purpose.

I admit that there is here a certain circularity in my argument since, as I have explained in the previous sections, I deny any substantial role of the entire concept of 'transitional public policy' as a matter of principle. Hence any 'usefulness' that could be attributed to the use of the concept in investment treaty arbitration is by its very nature linked to a more general acceptance of a formal role for transnational public policy, and vice versa. But a certain circularity here is inevitable.

I doubt the existence of a general acceptance of the notion of fundamental human rights, together with a corporate responsibility to respect human rights, as binding international law 'norms' in and of themselves. Marcoux attempts to give content to 'transnational public policy' in investment arbitration by not only focusing on the existence of international treaties containing these norms, but also on the basis of a rather vague 'international consensus' in respect of those norms. The entire concept of 'international consensus' despite being present in several definitions of 'transnational public policy' as discussed in the first section - can perhaps make sense if one applies it to jus cogens norms but otherwise it is nebulous at best. Moreover 'norms', such as the 'protection of fundamental human rights', and 'a corporate responsibility to respect human rights', would be part of an 'international consensus', but not binding as customary law or treaty law and through that door apply nonetheless as if it was binding. The entire discussion is reminiscent of the soft law debate, whereby international norms on human rights applicable in interstate 
relations were included in guidelines, codes of conduct and other non-binding instruments addressed to corporations ${ }^{55}$ which were then in turn used to showcase the existence of norms of international law binding on transnational corporations. ${ }^{56}$ Here also, when viewed from a public international law perspective of treaty-based arbitral tribunals, the application of norms based on an international 'consensus' sits uneasily with the fact that international legal norms, in order to be applied, need to (pre-)exist in a binding manner. ${ }^{57}$

On the rights or 'norms' identified by Marcoux: I have doubts that the 'corporate responsibility to respect human rights' is, or even can itself be, a norm, let alone one of 'public policy'. First, can one really say that there is an obligation for corporations to respect international human rights? John Ruggie does not make the claim that corporations have an international law obligation to respect human rights. The UN Guiding Principles (UNGP) are based on the 'Protect, Respect and Remedy'-Framework which rests on three pillars, including 'the corporate social responsibility to respect human rights, which means that business enterprises should act with due diligence to avoid infringing on the rights of others and to address adverse impacts with which they are involved. 58 Also, in Urbaser $v$ Argentina, the Tribunal clearly points out that, 'even though several initiatives undertaken at the international scene are seriously targeting corporations human rights conduct, they are not, on their own, sufficient to oblige corporations to put their policies in line with human rights law. 59 Secondly, if accepted, 'corporate responsibility to respect human rights' may at best be construed as a set of human rights obligations that corporations have under international or domestic law, and a breach of these would result

55 For a discussion, see Eric De Brabandere, 'Non-State Actors and Human Rights: Corporate Responsibility and the Attempts to Formalize the Role of Corporations as Participants in the International Legal System' in Jean d'Aspremont (ed), Participants in the International Legal System: Multiple Perspectives on Non-State Actors in International Law (Routledge 2011) 268-83.

$5^{6}$ See for example David Weissbrodt and Muria Kruger, 'Norms on the Responsibilities of Transnational Corporations and Other Business Corporations and Other Business Enterprises with Regard to Human Rights' (2003) 97 AJIL 901, 921 and David Kinley and Junko Tadaki, 'From Talk to Walk: The Emergence of Human Rights Responsibilities for Corporations at International Law' (2004) 44 Va J Intl L 931, 962-92.

57 See Jan Klabbers, 'The Undesirability of Soft Law' (1998) 67 Nordic JIL 381-91 and Jean d'Aspremont, 'Softness in International Law: A Self-Serving Quest for New Legal Materials' (2008) 19 EJIL 1075-93.

$5^{8}$ John Ruggie, 'Report of the Special Representative of the Secretary-General on the Issue of Human Rights and Transnational Corporations and Other Business Enterprises' (Human Rights Council, 21 March 2011) UN Doc A/HRC/17/31, para 6.

59 Urbaser SA and Consorcio de Aguas Bilbao Bizkaia, Bilbao Biskaia Ur Partzuergoa $v$ The Argentine Republic, ICSID Case No ARB/o7/26, Award (8 December 2016) para 1195. 
in responsibility for such breach. But the 'responsibility to respect' can conceptually not easily be categorized as a norm itself. Thirdly, what constitutes 'fundamental human rights' also is vague. If fundamental human rights norms are peremptory norms, what is the added value of discussing them as fundamental human rights norms in the context of investment treaty arbitration? Their effect would, in any event, not be any different from jus cogens norms qualitate qua.

More fundamentally, even if one were to accept that 'the protection of fundamental human rights', 'a corporate responsibility to respect human rights', and the 'rights of Indigenous Peoples' can be conceptualized as transnational public policy, what effect would this have on the treaty dispute and/or competence of an arbitral tribunal? I do not consider that this has any effect other than the effect the norms in and of themselves would have. To take a very simple and binary approach to international law to make my argument: if a norm exits, it applies; if a rule is not binding or inexistent, it simply does not, or cannot, apply. Based on this, any conceptualization of a norm as transnational public policy does not add much to the reality that an international law norm that exists can be applied without resort to the vague concept of transitional public policy. 'Breaching' transnational public policy does not do anything else than what a 'simple' breach of the norm in question would do. Framing a norm as part of transnational public policy does not change the inherent application (and limits thereto) of the norm in investment treaty arbitration. Where and how human rights (irrespective of whether one looks at the rights of indigenous peoples, 'fundamental' human rights, or the obligations of corporations in respect of human rights norms) can be considered in investment treaty arbitration is in fact relatively clear. Several authors have already outlined the various 'entry points' for human rights norms in investment arbitration. ${ }^{60}$ Presenting or conceptualizing (some of) these as transnational public policy offers limited added value, both legally and conceptually.

Finally, Marcoux, in my view, also stretches the concept of transnational public policy, even beyond its application in commercial arbitration. As explained above, transnational public policy in fact requires an arbitral tribunal to consider norms which otherwise would not be applicable; it can rely on

6o See Vivian Kube and Ernst-Ulrich Petersmann, 'Human Rights Law in International Investment Arbitration' (2016) EUI Working Paper No LAW 2016/o2 <http://cadmus .eui.eu/handle/1814/38985> accessed 13 July 2020. See also Eric De Brabandere, 'Human Rights and International Investment Law' in Marcus Krajewski and Rhea T Hoffmann (eds), Research Handbook on Foreign Direct Investment (Edward Elgar 2019) 619-45 and Patrick Dumberry and Gabrielle Dumas-Aubin, 'When and How Allegations of Human Rights Violations Can Be Raised in Investor-State Arbitration' (2012) 13 JWIT 36o-65. 
those norms to vacate rights derived from a contract. But transnational public policy in international arbitration as such does not 'impose' additional obligations on the parties; it adds a set of norms to the legal regime to be applied by the tribunal. It does not have the effect of imposing obligations on the parties; transnational public policy sanctions transgression of the norms comprised in the concept by, for example, refusing the recognition of rights deriving from treaties obtained by corruption. Transposed to the investment treaty arbitration level, using transnational public policy to effectively impose obligations to respect certain human rights therefore exceeds the initial objective and effect of transnational public policy in commercial arbitration.

Conclusion: Making 'Sense' of Arbitral Practice and Methodological Choices and Their Implications

In his response to the present reply, ${ }^{61}$ Marcoux emphasizes the need to 'make sense' of the practice of investment tribunals which refers to and uses 'transnational public policy'. In doing so, he emphasizes the need to analyze a given practice from an interdisciplinary perspective, including social theory and the 'social meaning of a practice' ${ }^{62}$ Of course, the methodological choices made to analyze the practice of arbitral tribunals in relation to 'transnational public policy' are perfectly defendable. But this is not the main point of my criticism. An interdisciplinary or social theory approach to the practice of arbitral tribunals may have merit, and so is Marcoux' argument. My main issue is that the interdisciplinary and social theory analysis at a certain point shifts towards making normative claims since the argument is that tribunals have generated a normative pull toward a requirement for foreign investors to comply with the doctrine [of transnational public policy].63 And it are precisely these normative claims that I have issue with. It is one thing to speak different languages and use different methodologies, but it is another to switch from one to the other.

I am therefore not necessarily advocating for an exclusive reliance on traditional 'doctrinal understanding of the practice of tribunals' 64 which is the main point of criticism of Marcoux on the present reply. Rather, I want to emphasize

61 Jean-Michel Marcoux, 'The Need to Make Sense of a Practice in Investment Arbitration: A Response to Eric De Brabandere' (2020) 21(6) JWIT 867-79.

62 ibid 872.

63 ibid 875 .

64 ibid 869. 
the need to exercise caution when deriving normative implications from tribunal practice, through whatever methodology or theory used. 'Transnational public policy' is not an indeterminate concept - it has a certain (core) meaning in international commercial arbitration. It is precisely that understanding of transnational public policy that is inapplicable in the treaty-based arbitration context. The practice of or references made by arbitral tribunals to that concept does not change the fundamentally distinct nature of international commercial arbitration and treaty-based investment arbitration. Beyond this main point I also consider, if one were to admit that certain 'norms' can be encapsulated in a transnational public policy in the treaty arbitration context, that the usefulness of presenting these as part of a 'transnational public policy' has little added-value from a normative perspective. Grouping 'norms' under the umbrella of transnational public policy does not change the applicability or not of the norms in question.

I side with Marcoux on the idea that trying to make sense of arbitral practice is essential. The practice of investment arbitration indeed, as I have acknowledged in the introduction, contributes to shaping the regime that is international investment law. However, making sense of a practice can and should also result in a finding that the given practice in actual fact does not make sense, or that the practice can make sense from a social theory perspective, but not from a normative perspective. 